\title{
Neonatal Morbidity in Macrosomic Infants
}

\author{
Makrozomik Bebeklerde Neonatal Morbidite \\ (D) Asuman Güney, (D) Didem Arman, (D) Serdar Cömert \\ İstanbul Training and Research Hospital, Clinic of Neonatology, İstanbul, Turkey
}

\begin{abstract}
Introduction: Macrosomy is defined as birth weight being over 4000 grams. Neonatal complications are common in macrosomic infants. In this study, we aimed to compare macrosomic infants with normal weighed infants in terms of neonatal morbidities.
\end{abstract}

Methods: Macrosomic infants born between 01.01.2015 and 31.08.2015 were included in the study. The study group consisted of 100 infants (group 1) with a birth weight above 4000 grams and the control group consisted of 100 infants (group 2) weighing between 2500-4000 grams. Antenatal, natal and postnatal data of macrosomic and normal weighed infants were recorded. Statistical analysis was performed using SPSS 22.0 for Windows.

Results: Maternal age, macrosomic sibling history, prenatal body mass index (BMI), weight gain during pregnancy were found to be significantly higher in the macrosomic group ( $p=0.047, p=0.001, p=0.003$, and $p=0.007$, respectively). Gestational week and male gender ratio of infants were higher in the macrosomic group. In the macrosomic group, 1-minute Apgar score was significantly lower, but there was no significant difference in 5-minute Apgar score. The rate of positive pressure ventilation was higher in the macrosomic group $(p=0.04)$. The incidence of clavicle fracture, caput succadeneum and ecchymosis was higher in the macrosomic group ( $p=0.004, p=0.005$ and $p=0.022$, respectively), but there was no significant difference in plexus brachialis paralysis and cephal hematoma. While hypoglycemia and pathological weight loss were significantly higher in the macrosomic group ( $p=0.03, p=0.038$, respectively), there was no difference between the groups in terms of other variables.

Conclusion: Maternal age, history of macrosomic birth, high prenatal BMI, excess weight gain during pregnancy and gestational diabetes in the mother constitute risk for macrosomic birth. Birth trauma, hypoglycemia and pathological weight loss are common in these infants. For this reason, it is very important to carry out the physical examination of macrosomic infants carefully after birth and to closely monitor them with blood sugar and weight control.

Keywords: Macrosomia, newborn, morbidity

\section{öZ}

Amaç: Makrozomi; doğum ağırlığının 4000 gramın üzerinde olması şeklinde tanımlanır. Makrozomik bebeklerde neonatal komplikasyonlarla sık karșılașılmaktadır. Bu çalıșmada makrozomik bebeklerle normal tartılı bebekleri neonatal morbiditeler açısından karşılaştırmayı amaçladık.

Yöntemler: Çalıșmaya 01.01.2015 ve 31.08.2015 tarihleri arasında doğan makrozomik bebekler dahil edildi. Çalıșma grubu, doğum ağırlığı 4000 gramın üstü 100 bebekten (grup 1), kontrol grubu ise ağılığı 2500-4000 g arasında normal tartılı 100 bebekten (grup 2) olușuyordu. Makrozomik ve normal tartılı bebeklerin antenatal, natal ve postnatal bilgileri kaydedildi. İstatistiksel değerlendirme Windows SPSS 22.0 programı ile yapıldı.

Bulgular: Makrozomik grupta anne yașı, makrozomik kardeș öyküsü, gebelik öncesi yüksek vücut kitle indeksi (VKI), gebelikteki kilo alımı istatistiksel olarak anlamlı yüksek $(p=0,047, p=0,001, p=0,003$ ve $p=0,007)$ saptandı. Bebeklerin gestasyon haftası ve erkek cinsiyet oranı makrozomik grupta daha yüksekti. Makrozomik grupta 1. dakika Apgar değeri anlamlı olarak daha düşükken, 5. dakika Apgar değerinde anlamlı farklıık saptanmadı. Pozitif basınçlı ventilasyon uygulama oranı makrozomik grupta daha yüksekti $(p=0,04)$. Klavikula kırığı, kaput suksadenum ve ekimoz görülme oranı makrozomik grupta daha yüksek ( $p=0,004, p=0,005$ ve $p=0,022)$ iken pleksus brakialis paralizisi ve sefal hematom açısından anlamlı fark bulunmadı. Hipoglisemi ve patolojik tartı kaybı makrozomik grupta anlamlı oranda yüksek ( $p=0,03$, $\mathrm{p}=0,038)$ iken diğer değișkenler açısından gruplar arasında fark yoktu.

Sonuç: Anne yaşı, makrozomik doğum öyküsü, gebelik öncesi yüksek VKI, gebelikte fazla kilo alımı ve annede gestasyonel diyabet makrozomik doğum için risk oluşturur. Bu bebeklerde doğum travması, hipoglisemi ve patolojik tartı kaybı sıktır. Bu nedenle makrozomik bebeklerin doğum sonrası fizik muayenelerinin dikkatli yapılması, kan şekeri ve tartı kontrolü ile yakın izlenmeleri çok önemlidir.

Anahtar Kelimeler: Makrozomi, yenidoğan, morbidite 


\section{Introduction}

Birth weight is one of the most important factors affecting neonatal morbidity and mortality. Fetal macrosomia or large for gestational age is defined as birth weight above $90^{\text {th }}$ percentile for gestational age or more than 4000 grams $(1,2)$. However, there is no consensus on the limit of birth weight. In various studies, infants with birth weight above $4000 \mathrm{~g}$, $4200 \mathrm{~g}$ and $4500 \mathrm{~g}$ have been identified as macrosomic. However, more commonly used and accepted form (infants more than 4000 grams) was used in our study $(3,4)$. Many risk factors have been identified in macrosomy and usually several factors coexist. These risks include male gender, postmaturity, history of macrosomia in the previous sibling, presence of obesity or diabetes in the mother, and macrosomia-related syndromes such as Beckwith-Wiedemann syndrome (2).

Fetal macrosomia is associated with an increased risk of complications for the mother and fetus or newborn $(3,4)$. Perinatal risks associated with macrosomia include birth trauma, shoulder dystocia, brachial plexus injuries, perinatal asphyxia, and death (3-6). Neonatal risks associated with macrosomia can be listed as hypoglycemia, hematologic disorders and electrolyte disorders $(3,4)$. Increased caesarean section, large perineal tears and severe hemorrhage are among the maternal complications $(7,8)$. Perinatal mortality is twice as high in neonates with birth weight above 4500 grams compared to neonates between 25003500 grams. The most common cause for this is birth traumas. The most common birth trauma in macrosomic infants is shoulder dystosis, which may result in fractures of the clavicle and humerus leading to brachial plexus paralysis (2). Much more serious problems, perinatal asphyxia and death may occur due to difficult labor.

In this study, we aimed to compare neonatal morbidities in macrosomic infants and normal weighed infants with a birth weight of 2500-4000 g.

\section{Methods}

One hundred macrosomic infants and 100 controls that were born in our hospital were included in the study. The study group consisted of 100 macrosomic cases with a birth weight of more than 4000 grams, and the control group consisted of 100 subjects with a normal weight weighing between 2500-4000 grams. Term infants older than 37 weeks
$+6 / 7$ days without missing data in mother and infant files were included in the study. Preterm infants under 37 weeks $+6 / 7$ days of age, infants from multiple pregnancies and infants with intrauterine growth and development restriction were not included in the study. Ethics Committee approval was obtained for the study from İstanbul Haseki Training and Research Hospital Medical Research Ethics Committee (decision no: 255, date: 04.11.2015). An informed consent form was prepared and families were informed, and informed consent was obtained for participation in the study.

Maternal ages, gravidity and parity, prenatal body mass index (BMI), weight gain during pregnancy, presence of gestational diabetes mellitus (GDM) or gestational hypertension (GHT), mode of delivery, and history of macrosomic sibling were recorded. Birth weight of newborns, physical examination findings, presence of perinatal asphyxia, Apgar scores, presence of condition requiring intervention after birth, cord or $1^{\text {st }}$ hour blood gas analysis, problems such as birth trauma, presence of respiratory distress, hypoglycemia, hypocalcemia, hyperbilirubinemia and polycythemia, and pathological weight loss were also recorded.

Infants weighing over 4000 grams were considered macrosomic. Hypoglycemia was defined as venous glucose level $<40 \mathrm{mg} / \mathrm{dL}$. Capillary venous hematocrit level above $65 \%$ was defined as polycythemia and calcium level below $8 \mathrm{mg} / \mathrm{dL}(1.1 \mathrm{mmol} / \mathrm{L})$ as hypocalcemia in term infants. The limit of hyperbilirubinemia was evaluated according to the American Academy of Pediatrics 2004 guidelines. Weight losses of more than $10 \%$ during neonatal examination were accepted as pathological weight losses.

\section{Statistical Analysis}

Statistical Package for Social Sciences (SPSS for Windows 22.0) was used for statistical analysis. Mean, standard deviation, median, minimum, maximum, number and percentage values were used in descriptive statistics of the data. The distribution of variables was measured by Kolmogorov-Smirnov test. Mann-Whitney $U$ test was used to analyze the quantitative data. Chi-square test was used for the analysis of qualitative data and Fischer's test was used when the chi-square test conditions were not met. Significance was evaluated at $p<0.05$.

\begin{tabular}{|l|l|l|l|}
\hline \multicolumn{2}{|l|}{ Table 1. Comparison of macrosomic infants and control group in terms of neonatal and maternal characteristics } \\
\hline & Macrosomic group & Control group & p \\
\hline Gestational age, weeks & $39.8 \pm 1.1$ & $39.0 \pm 1.0$ & 0.001 \\
\hline Mode of delivery (n), NVD-C/S & $43 / 57$ & $43 / 57$ & - \\
\hline Gender (n) (female/male) & $30 / 70$ & $51 / 49$ & 0.002 \\
\hline Maternal age (years) (mean \pm SD) & $29.6 \pm 5.5$ & $28.2 \pm 5.9$ & 0.047 \\
\hline Gravidity (median) & 3 & 3 & 0.326 \\
\hline Parity (median) & 2 & 2 & 0.645 \\
\hline BMI (mean \pm SD) & $27.0 \pm 5.6$ & $24.5 \pm 3.9$ & 0.003 \\
\hline Weight gain during pregnancy (kg) (mean \pm SD) & $13.9 \pm 5.8$ & $11.6 \pm 4.8$ & 0.007 \\
\hline GDM & 16 & 7 & 0.046 \\
\hline GHT & 1 & 2 & 0.561 \\
\hline History of macrosomic sibling & 28 & 10 & 0.001 \\
\hline NVD: normal vaginal delivery, C/S: cesarean section, SD: standard deviation, BMI: body mass index, GDM: gestational diabetes mellitus, GHT: gestational hypertension
\end{tabular}




\section{Results}

The study group consisted of 100 macrosomic infants and the control group consisted of 100 infants born at normal weight. The mean gestational week (GW) in the macrosomic group was 39.8 11.1 weeks, whereas the mean GW in the control group was $39.0 \pm 1.0$ weeks (Table 1). GWs of macrosomic infants were found to be significantly higher $(p=0.001)$. When the mode of delivery was examined, it was found that $43 \%(n=43)$ of macrosomic infants were born with normal vaginal delivery. There was no difference between the two groups in terms of mode of delivery. In the macrosomic infant group, male gender was found to be significantly predominant $(p=0.002)$.

The mean age of the mothers was $29.6 \pm 5.5$ years in the macrosomic infant group and $28.2 \pm 5.9$ years in the control group. The maternal age of macrosomic infants was significantly higher $(p=0.047)$. Mean BMI was $27.0 \pm 5.6$ in mothers of macrosomic infants and 24.5 \pm 3.9 in mothers of control group. The difference between the two groups was statistically significant $(p=0.003)$. The mean weight gain of mothers of macrosomic infants during pregnancy was $13.9 \pm 5.8 \mathrm{~kg}$. However, this value was $11.6 \pm 4.8 \mathrm{~kg}$ in the control group. Mothers of macrosomic infants gained significantly more weight during pregnancy $(p=0.007)$. There was no difference between the mothers of the two groups in terms of gravidity and parity ( $p=0.326$ and $p=0.645$, respectively). While gestational GDM was detected in 16 mothers in the macrosomic group, GDM was detected in only seven mothers in the control group. The difference between the two groups was statistically significant $(p=0.046)$. There was no difference between the two groups in terms of GHT ( $p=0.561)$. History of macrosomic sibling was detected in 28 infants in the macrosomic group and in 10 infants in the control group. The history of having macrosomic siblings was significantly higher in the macrosomic group $(p=0.001)$.

While there was no difference between the blood gas $\mathrm{pH}$ values of the macrosomic group and the control group $(p=0.071)$, a significant difference was found in terms of base excess, carbon dioxide levels and bicarbonate values ( $p=0.046, p=0.128, p=0.028$, respectively) (Table 2). While 1-minute Apgar scores were significantly lower in the macrosomic group ( $p=0.001$ ), 5 -minute Apgar scores were similar in both groups $(p=0.381)$.

No asphyxia cases were detected in the macrosomic group and control group (Table 3). The incidence of postnatal positive pressure ventilation (PPV) in macrosomic infants was significantly higher $(p=0.001)$. While clavicle fracture was significantly higher in the macrosomic infant group $(p=0.004)$, there was no difference in plexus paralysis $(p=0.497)$. In the macrosomic infants, the caput succadeneum and ecchymosis were significantly higher $(p=0.005$ and $p=0.022$, respectively). Hypoglycemia and weight loss were significantly higher in macrosomic infants ( $p=0.030$ and $p=0.038$, respectively), whereas there was no difference in terms of transient tachypnea of newborn, jaundice, hypocalcemia, polycythemia and hospitalization rates.

\section{Table 2. Comparison of cord blood gas values and Apgar scores}

\begin{tabular}{|l|l|l|l|}
\hline & Macrosomic group & Control group & $\mathbf{p}$ \\
\hline $\mathrm{pCO}_{2}(\mathrm{mmHg})$ & $7.2 \pm 0.2$ & $7.3 \pm 0.1$ & 0.071 \\
\hline $\mathrm{HCO}_{3}(\mathrm{mmol} / \mathrm{L})$ & $47.4 \pm 10.2$ & $50.4 \pm 8.8$ & 0.018 \\
\hline $\mathrm{BE}(\mathrm{mmol} / \mathrm{L})$ & $22.3 \pm 2.5$ & $23.1 \pm 2.4$ & 0.028 \\
\hline 1-minute Apgar score (median) & $-1.5 \pm 2.7$ & $-0.6 \pm 2.8$ & 0.046 \\
\hline 5-minute Apgar score (median) & 7 & 8 & 0.001 \\
\hline
\end{tabular}

Table 3. Comparison of macrosomic infants with control group in terms of neonatal morbidities

\begin{tabular}{|c|c|c|c|}
\hline & Macrosomic group (n) & Control group $(\mathrm{n})$ & $\mathbf{p}$ \\
\hline Asphyxia & 0 & 0 & - \\
\hline Need for PPV & 4 & 0 & 0.001 \\
\hline Fracture of the clavicle & 8 & 0 & 0.004 \\
\hline Plexus paralysis & 2 & 0 & 0.497 \\
\hline Cephal hematoma & 3 & 7 & 0.194 \\
\hline Caput succadeneum & 16 & 4 & 0.005 \\
\hline Ecchymosis & 13 & 4 & 0.022 \\
\hline TTN & 19 & 15 & 0.451 \\
\hline Hypoglycemia & 9 & 2 & 0.030 \\
\hline Hypocalcemia & 2 & 0 & 0.497 \\
\hline Polycythemia & 4 & 2 & 0.407 \\
\hline Weight loss & 15 & 6 & 0.038 \\
\hline Hospitalization & 35 & 30 & 0.450 \\
\hline
\end{tabular}




\section{Discussion}

In our study, we found that the age of mothers of macrosomic infants was high ( $p=0.047)$. Similar to our results, Akın et al. (9) and Wollschlaeger et al. (10) also reported that mothers who give birth to macrosomic infants had a higher age. Adesina and Olayemi (11) reported that there was no difference between macrosomic infants and the control group in terms of maternal age. In our country, Oral et al. (12) reported that maternal age above 35 years was an important risk factor for macrosomic delivery.

Prenatal BMI is an important factor affecting fetal growth (13). In our study, we found that BMI and weight gain of mothers who delivered macrosomic infants were significantly higher, which supported this view. Alberico et al. (14) showed that the risk of macrosomic birth of obese mothers was 1.7 times higher. It was reported that the main factor that increased the risk of macrosomic birth in obese mothers was weight gain during pregnancy (15). Similar to the results in our study, Li et al. (16) reported that prenatal BMI and weight gain during pregnancy were important and modifiable risk factors for macrosomia.

Akın et al. (9) reported that gender was male in $66 \%$ of macrosomic infants. According to the results of a multicenter study, a significant relationship was found between male gender and macrosomia (10). In the examination of macrosomic infants, Jazayeri (4) stated that the male gender was higher in infants weighing more than 4500 gr. Similar to the results of Wollschlaeger et al. (10) and Tomic et al. (17), we found that the number of male infants was higher among macrosomic infants $(10,17)$.

Contrary to previous studies, we could not find a significant difference between the macrosomic group and the control group in terms of mode of delivery. Akın et al. (9) reported a C-section (C/S) rate of $37.3 \%$ in macrosomic deliveries. In the same study, they stated that low birth trauma and asphyxia rates in their study could be explained by high $\mathrm{C}$ / S rates. In Istanbul, Oral et al. (12) found this rate as $28.8 \%$. In a study examining macrosomic births in 23 developing countries, it was found that macrosomia caused an increased risk of C/S (16).

In the study of Mohammadbeigi et al. (18) comparing macrosomic infants with normal weighed infants, no difference was found in terms of blood pressure, gestational age and Apgar scores. Another study demonstrating that Apgar scores of macrosomic infants did not differ from normal weighed infants was reported by Talay et al. (19). In our study, 1-minute Apgar score was found to be lower in macrosomic infants; however, no difference was found in terms of 5-minute Apgar score. In another study, it was reported that there was no difference in terms of 5-minute Apgar score, but that comparison of macrosomic infants weighing 4000-4449 $\mathrm{g}$ and $>4500$ g revealed a significant difference (20). In our study, we found that the frequency of PPV applications in macrosomic infants was significantly higher. In the study of Yıldırım et al. (21) they reported that macrosomic infants born from diabetic mothers needed more ventilation support in the delivery room than other macrosomic babies. In another study, the need for neonatal resuscitation was significantly higher in infants of obese mothers compared to non-obese mothers (22).

The risk of birth trauma and asphyxia increases in macrosomic infants. In the study of Akın et al. (9), no difference was found in terms of early neonatal mortality and asphyxia. We also did not find any significant difference between macrosomic and control groups in terms of intubation and asphyxia. In the study performed by Demirören et al. (23), perinatal asphyxia findings were found in approximately $1 / 3$ of the macrosomic cases, and it was stated that delivery by $\mathrm{C} / \mathrm{S}$ might be preferred for infants thought to be macrosomic.

In a study investigating fetal macrosomia risk factors, it was stated that GDM, history of macrosomic sibling and maternal preeclampsia increased the risk of macrosomia by 11.9, 3.8 and 3.3 fold, respectively (18). Maternal impaired glucose intolerance, multiparity, history of macrosomic delivery, excess weight gain during pregnancy and male fetus were defined as risk factors for macrosomia. It has been shown that the incidence of macrosomia in pregnant women with two or more of these risks reaches $32 \%$ (23). In our study, high rate of macrosomic sibling history in the macrosomic group supported the literature data.

In our study, the incidence of clavicle fracture, caput succadeneum and ecchymosis was increased in macrosomic infants, but no difference was found in terms of plexus brachialis paralysis and cephal hematoma. Linder et al. (24) found that the rate of birth trauma was higher in the macrosomic group. In the study by Al-Wazzan and Sarsam (25), there was a significant difference in Erb paralysis in the macrosomic group, but no difference was found in terms of clavicle fracture. In the study of Akın et al. (9), there was a significant difference in clavicle fracture, but there was no difference in brachial plexus paralysis and cephal hematoma; however, a significant difference was found in the macrosomic group when evaluated by taking into account the whole birth traumas.

Bandika et al. (26) have shown that the frequency of hypoglycemia and hypocalcemia is increased in infants over 4250 grams. In the same study, the risk of hypoglycemia was found to be $21 \%$ in large for gestational age infants, but it was shown that the risk of hypoglycemia increased as the birth weight increased. Also, Mohammadbeigi et al. (18) showed that neonatal hypoglycemia was increased 4.7 fold in newborns over 4000 grams. In accordance with the literature, hypoglycemia was found to be significantly higher in the macrosomic group in our study. In the study of Linder et al. (24), hypoglycemia was observed in symmetrical macrosomic infants with a similar frequency as normal weighed infants, but closer blood glucose monitoring was required in asymmetric macrosomic infants).

In studies comparing macrosomic and normal weighed infants, pathological weight loss after birth was not evaluated much. In our study, we found that the pathological weight loss was higher in the macrosomic group compared to normal weighed infants. In a study comparing macrosomic infants with and without diabetic mothers, Yıldırım et al. (21) showed that pathological weight loss was higher in the non-diabetic group ( $42 \%$ vs $27 \%$ ). Therefore, close monitoring of macrosomic infants in terms of postpartum weight loss is important.

\section{Conclusion}

High maternal age, history of macrosomic delivery, high BMI before pregnancy, excess weight gain during pregnancy and maternal GDM pose a risk for macrosomic birth. Birth trauma, hypoglycemia and pathological weight loss are common in macrosomic infants. Therefore, 
it is important to perform careful physical examinations of macrosomic babies in the postnatal period and to closely monitor them with blood sugar and weight control.

Ethics Committee Approval: Committee approval was obtained for the study from İstanbul Haseki Training and Research Hospital Medical Research Ethics Committee (decision no: 255, date: 04.11.2015).

Informed Consent: An informed consent form was prepared and families were informed, and informed consent was obtained for participation in the study.

Peer-review: Externally peer-reviewed.

Author Contributions: Concept - S.C.; Design - S.C.; Data Collection and/or Processing - A.G.; Analysis and/or Interpretation - S.C.; Literature Search - S.C., D.A.; Writing Manuscript - A.G.

Conflict of Interest: The authors have no conflict of interest to declare.

Financial Disclosure: The authors declared that this study has received no financial support.

\section{Kaynaklar}

1. American College of Obstetricians and Gynaecologists. Fetal macrosomia. Practice Bulletin No:22 Washington, DC: ACOG, 2000

2. Can G, İnce Z. Preterm Doğanlar, İntrauterin büyüme geriliği, makrozomi, çoğul gebelikler. Neyzi 0, Ertuğrul T (editörler). Pediatri 4. Baskı, İstanbul: Nobel Tıp Kitapevleri; 2010.p.367-85.

3. Henriksen T. The macrosomic fetus: a challenge in current obstetrics. Acta Obstet Gynecol Scand 2008; 87: 134-45.

4. Jazayeri A. Macrosomia. Accessed August 24, 2008 at http://www.emedicine. $\mathrm{com} / \mathrm{med} / \mathrm{TOPIC} 3279$.

5. Lindsay CA. Pregnancy complicated by diabetes mellitus. In: Martin RJ, Fanaroff AA, Walsh MC (eds). Fanaroff and Martin's Neonatal-Perinatal Medicine. Diseases of the Fetus and Infant (8th ed). Philadelphia: Mosby Elsevier; 2006: 326-7.

6. Acker DB, Sachs BP, Friedman EA. Risk factors for shoulder dystocia. Obstet Gynecol 1985; 66: 762-68.

7. Haram K, Pirhonen J, Bergsjo P. Suspected big baby: A difficult clinical problem in obsterics. Acta Obstet Gynecol Scand 2002; 81: 185-94

8. Weissmann-Brenner A, J. Simchen M, Zilberberg E, Kalter A, Weisz B, Achiron $R$, et al. Maternal and neonatal outcomes of macrosomic pregnancies. Med Sci Monit 2012; 18: 77-81.

9. Akın Y, Cömert S, Turan C, Pıçak A, Ağzıkuru T, Telatar B. Macrosomic newborns: A 3-year review. The Turkish Journal of Pediatrics 2010; 52: 378-83.

10. Wollschlaeger K, Nieder J, Köppe I, Hartlein K. A study of fetal macrosomia. Arch Gynecol Obstet 1999; 263: 51-5.
11. Adesina OA, Olayemi O. Fetal macrosomia at the University College Hospital, Ibadan: A 3 year review. J Obstet Gynaecol 2003; 23: 30-3.

12. Oral E, Cağdaș A, Gezer A, Kaleli S, Aydınlı K, Ocer F. Perinatal and maternal outcomes of fetal macrosomia. Eur J Obstet Gynecol Reprod Biol 2001; 99: 167-71.

13. Yu Z, Han S, Zhu J, Sun X, Ji C, Guo X. Pre-pregnancy body mass index in relation to infant birth weight and offspring overweight/obesity: A systematic review and meta-analysis. Plos One 2013; 8: 61627.

14. Alberico S, Montico M, Barresi V, Monasta L, Businelli C, Soini V, et al. The role of gestational diabetes, pre-pregnancy body mass index and gestational weight gain on the risk of newborn macrosomia: result from a prospective multicentre study. BMC Pregnancy and Childbirth 2014; 14: 23.

15. Di Benedetto A, D’anna R, Cannata ML, Giordano D, Interdonato ML, Corrado F. Effects of pre-pregnancy body mass index and weight gain during pregnancy on perinatal outcome in glucose-tolerant women. Diabetes Metab 2012; 38: 63-7.

16. Li G, Kong L, Li Z, Zhang L, Fan L, Zou L et al. Prevalence of macrosomia and its risk factors in China: A Multicentre survey based on birth data involving 101,723 singleton term infants. Paediatr Perinat Epidemiol 2014; 28: 345-50.

17. Tomic V, Bosnjak K, Petrov B, Dikic M, Knezevic D. Macrosomic births at Mostar Clinical Hospital: A 2-year review. Bosn J Basic Med Sci 2007;7: 271-4

18. Mohammadbeigi A, Farhadifar F, Soufi zadeh N, Mohammadsalehi N, Rezaiee M, Aghaei M. Fetal Macrosomia: Risk factors, maternal, and perinatal outcome. Annals Of Medical and Health Sciences Research 2013; 3 :546-50.

19. Talay H, Akyol A, Özer A, Karaman E, Özdemir C, Ark HC. Bebek doğum tartısının maternal ve fetal komplikasyonlara etkisi. IKSST Derg 2014; 6: 6570 .

20. Gyurkovits Z, Kallo K, Bakki J, Katona M, Bito T, Pal A, et al. Neonatal outcome of macrosomic infants: An analysis of a two year period. Eur J Obstet Gynecol Reprod Biol 2011; 159: 289-92.

21. Yıldırım S, İnce Z, Çoban A, Durmuş S, Demirel A, Can G. Diyabetik ve diyabetik olmayan annelerden doğan makrozomik bebeklerde neonatal morbidite Cocuk Dergisi 2010; 10: 122-5.

22. Gaudet L, Wen SW, Walker M. The combined effect of maternal obesity and fetal macrosomia on pregnancy outcomes. J Obstet Gynaecol Can 2014; 36 : 776-84

23. Demirören K, Demirören S, Yüksekkaya HA, Koç H. Anneleri diabetik olmayan makrozomik bebeklerde komplikasyonlar. Fırat Üniversitesi Sağlık Bilimleri Tıp Dergisi 2008; 22: 81-6.

24. Linder N, LahatY, Kogan A, Fridman E, Kouadio F, Melamed N, et al. Macrosomic newborns of non-diabetic mothers: anthropometric measurements and neonatal complications. Arch Dis Child Fetal Neonatal Ed 2014; 99: 353-8.

25. Al-Wazzan RN, Sarsam SD. Fetal macrosomia maternal and perinatal Outcome. Al-Kindy Col Med J 2011; 7: 50-5.

26. Bandika VL, Were FN, Simiyu ED, Oyatsi DP. Hypoglycaemia and hypocalcaemia as determinants of admission birth weight criteria for term stable low risk macrosomic neonates. Afr Health Sci 2014; 14: 510-6. 